(i. Harris, without intimating to either of them what result 1 expected. Each, independently, reported a negative reaction. 'lle woman did not have syphilis.

'The buld recital of the fucts gives no intimation of the tense misery of the situation. Here was a guiltless yourn mmarried woman-worthy to be the wife or daughter of one of the best of us-whose life seemed to her and her family to be blasted by syphilis, and who might have gone to her dying day with the conviction that she had syphilis, if Jer doctor had not been unwilling to aceept as finul a Wasser. mann report that had been oflered as final evislence. The only way to renlize the horror of such a situation is to iry to imngine the patient one of the innocent women of one's own family.

This is not a mique case in my experience; I have had several of this character. I know at least two syphilophobes who are going about in constant fear lest they have syphilis, bectuse of mistuken diagnoses of syphilis based on mureliable Wassermanns. And the sometimes appalling character of these mistakes of a positive Wassermann in the absence of syphilis impels me to call attention to them.

Undoubtedly a good many unreliable Wassermanns aro heing made. The greatest fault is carelessness in technic. Another source of error is old blood. Jlood two days old, even when kept in an ice-box, is mureliable for the test; and much more so if it has been kept at car temperature while in transit to $n$ distant laboratory. Finally, some careful and ronscientions but overzenlous workers are drawing their test so fine in order to increase its sensitiveness that their rendings sometimes become mroliable.

This eriticism is not directed against the Wassermaun as a. test. The Wassermam is all right, but it should he appre. cinter that it is open to error in manipulation. It is not linal and unimpeachable evidence, and in improbable eases, like the one mentioned, a positive reaction should not be accepted as thinl unless one can be perfectly sure of the reliability of the process by which it has been obtained. The temdency to aceept the result of a test as infallible is the old story of allowing too much weight to luboratory findings

as though they were above the common lumman frailty of error. The Wassermann reaction is but one fuct in the diagrodis of syphilis. It should be confirmed by other dingnostic evidence. In the very rare alsence of this, it is not too much cuntion to have two independent tests to check ench other. William A. Pusey, M.D., Chicago.

\section{The Paramecium as an Indicator of Pathologic Tissue Changes}

To the Editor:-The editorinl on the work of Underhill and Woodruff (Tuw Journal, Nov. 8, 1013, p. 1720), is justifled in every way. At the suggestion of Herbert Spencer Jennings of Johns Hopkins and under hịs guidance, about a year ago 1 began an investigation of the sudden development of ejubemics umong paramecia. Fvery now and again a race of Parmesium caudatem or Paramecium aurelia will lose its normul powers of multiplication. A division-rate of eight or sixteen a day may suddenly eease, and the race of paramecium m:y become almost sterile for a day or two and then be amihiluted.

We lave found many of these differences in division-rate and destruction to be due to specific hacterial troubles, such as the overgrowth of yooglea masses of putrefying organisms of the B. proteus group, the B. turgidus and the like. Of course, the numy racial and envirommental accidents that produce ance changes in the rate of division of paramecia are too numerous to allow the deduction to be made that this ena be used as an indientor of pathologic tissue change.

Lenari, K. Hirshibra, M.D., Baltimore.

Rest in the Treatment of Heart-Disease.-And last, but not least, rest. I say "last, but not least, rest," and I am álways tempted to utter the paraphrase: "Now abideth diet, drugs, rest, these three, but the greatest of these is rest."- F. J. Wethered, in (Tondon) Clinical Journal.

\section{Queries and Minor Notes}

ANONYMOUS COMMUNICATIONS and guerfes on postal cards will not be notleed. Every letter bust contain the writer's name and nadress, but these wlll be omitfed, on reculest.

USLS OH CHROMIUM SULIIATH IN MEUICING

To the balor:-ijense enlighten me nbout the clnims made for chromium sulphate M. Ji. M.

Answer-An Answer to a similar query was publisled in Tile Jouknat, lob, 4, 1911, p. 367.

In lis artiele published in the Monthly cyclopedia and Mrdical Bulletin, September, 1908, Dr. S. Kolipinski said, "At the anmul meeting of the American rhermpeutic Socioty, May, 1902, the writer read a concise paper on the "Therapenties of C'mominm Sulphate.' As far as lie knows, the statements there made lave not been confirmed, nor has this chemical attracted attention as a medicine."

Dr. Solipinski also said, "The disenses in which chromimm has been used with success are: cirrhosis of the female breast, cistration, menopause, functional impotency in men, cluronic alcoholisn, nervous vomitinr and vomiting in pregnancy, nemrasthenia, locomotor ataxia, exophthalmic goiter and the? migraines."

since that tius no literature has appeared on this subject, except as noted before, and the firm which puts out the prepuration of chromium sulplate still uses Dr. Kolipinski's juper as practically its sole advertising matter. There is no doubt that the substance lias been tried by clinicians who have falled to obtain satisfnetory results. If this were not the cnse, jeports of its use would have appenred in reputable medical journals before this time. It seems evident, therefore, that this substance has failed to satisfy the remarkable elaims made for it by its jutroducer.

\section{INFORMATION CONCLRNING VARIOUS TESTS}

To the Editor:-lense tell me where I can find " thorough deseription and Informution of low to make the following tests:

1. limge's test of ccrebrosplnal fluid in congenitul syphils.

2 . Complement-fixation test for gonorrhen.

3. Abrlerhalden's test for pregnancy.

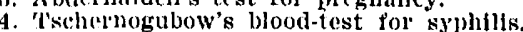

5. Kowiliski's blood-test for differental dagnosis of diabetes.

W. W. MCKinley, M.D., Girant City, Mo.

Answer.-1. See "A Manual of Venerenl Disenses," by Keogh, Melville, Leishman, Pollock and Harrison, p. 120.

2. Sec The Jounnar, Oet. 5, 1012, p. 1309. A description of the method is given by Lespinasse and Wolff, Illinois Med. Jour., Jamuary, 1013, p. 26.

3. See 'The Journal, Sept. 6, 1913, p. 788.

4. Tselnernogubow's test for syphilis is described in 'Tuw Journal, April 2, 1910, p. 114, by W. J. Butler.

5. Kowarski's method of testing for sugar in the mine is a modification of the phenyllydrazin test. It consists in mixing 5 drops of pure phenylhydrazin in a test-tube with 10 drops of acetic acid, gently shaking and then adding nbout 1 c.e. of a saturated solution of sodium chlorid. To the solic mass that forms is added from 3 to 5 c.e. of the urine, and the test-tube is then heated in the free fame for two minutes after its contents begin to boil. On coolingr, the osazone crystals separate from urines containing over '2 per cent. of sugar in one minute, and from weaker solutions in about five minutes. It will be noted that this method is merely a test for sugar and not for differential dingnosis of liubetes.

\section{RABIES AND 'IHE I'AS'TEUR 'J'REA'TMEN'T}

To the bitor:- I wish to ralse the following questlons 1. Ale there not more cases of rubles fil dog-bitten patients now than befole the l'asteur treatment became popularized?

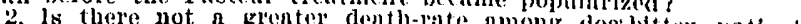
now than before the Insteur treatment becume, populare? 3. Is the fatulty among l'asteur-trented paf popmar? ant.?

4. What would be the denth-rate of desebittein pathents mings l'asteur treutment?

\section{L. (G. Llikaxd, M.l), Newton Falls, Ohlo.}

Answer.-1. The work of lasteur did not result in an increase in the number of cases of rabies in dog-bitten patients. He drew the attention of the medical profession and the laity to the disense, which had been comparatively neglected up to thut tine. Since the l'nstem trentment became popularized, cases of rabies have been recognized, 